Louisiana State University

LSU Digital Commons

Faculty Publications

School of Animal Sciences

$1-1-1999$

\title{
Use of western immunoblot analysis for testing moose serum for Brucella suis biovar 4 specific antibodies
}

\author{
Matthew D. Edmonds \\ School of Veterinary Medicine \\ Felicia M. Ward \\ School of Veterinary Medicine \\ Todd M. O'Hara \\ Philip H. Elzer \\ School of Veterinary Medicine
}

Follow this and additional works at: https://digitalcommons.Isu.edu/animalsciences_pubs

\section{Recommended Citation}

Edmonds, M., Ward, F., O'Hara, T., \& Elzer, P. (1999). Use of western immunoblot analysis for testing moose serum for Brucella suis biovar 4 specific antibodies. Journal of Wildlife Diseases, 35 (3), 591-595. https://doi.org/10.7589/0090-3558-35.3.591

This Article is brought to you for free and open access by the School of Animal Sciences at LSU Digital Commons. It has been accepted for inclusion in Faculty Publications by an authorized administrator of LSU Digital Commons.

For more information, please contact ir@lsu.edu. 


\section{Use of Western Immunoblot Analysis for Testing Moose Serum for Brucella suis biovar 4 Specific Antibodies}

Matthew D. Edmonds, ${ }^{1}$ Felicia M. Ward, ${ }^{1}$ Todd M. O'Hara, ${ }^{2}$ Philip H. Elzer, ${ }^{1,3,4}{ }^{1}$ Department of Veterinary Microbiology and Parasitology, Louisiana State University School of Veterinary Medicine, Baton Rouge, Louisiana 70803, USA, ${ }^{2}$ Department of Wildlife Management, North Slope Borough, Barrow, Alaska 99723, USA; ${ }^{3}$ Department of Veterinary Science, Louisiana State University Agricultural Center, Baton Rouge, Louisiana 70803, USA; and ${ }^{4}$ Corresponding author (e-mail: pelzer@unix1.sncc.Isu.edu).

ABSTRACT: To determine if 12 moose (Alces alces) from northern Alaska with agglutinating antibodies specific for Brucella spp. had been exposed to either B. suis biovar 4 or B. abortus biovar 1 , western immunoblot serologic analysis was performed. Differential serologic responses to strain specific A and $\mathrm{M}$ antigenic variances of the lipopolysaccharide O-polysaccharide sugar allowed strain identification. Prior to examination, test sera were absorbed with killed whole cells from either B. abortus biovar 1 , containing predominately $\mathrm{A}$ antigen $\left(\mathrm{A}^{+} \mathbf{M}^{-}\right)$; B. melitensis biovar 1 , containing essentially $\mathbf{M}$ antigen $\left(\mathrm{A}^{-} \mathrm{M}^{+}\right)$; or B. suis biovar 4 , containing both antigenic types $\left(\mathrm{A}^{+} \mathbf{M}^{+}\right)$. The resulting sera were then examined by western immunoblot for recognition of either $B$. abortus biovar $1, B$. melitensis biovar 1 , or B. suis biovar 4 cell lysates. The results of this study indicate that these moose were exposed to B. suis biovar 4 , a known pathogen of caribou (Rangifer tarandus) from arctic Alaska.

Key words: Alces alces, Brucella suis biovar 4, moose, serology, survey, western immunoblot.

Brucellosis is a serious, debilitating disease characterized by a variety of signs, including abortion, infertility, arthritis, osteomyelitis and mortality in domestic and wildlife species (Enright, 1990). Brucellosis is caused by the gram negative facultative, intracellular pathogens of the genus Brucella, including Brucella abortus, B. melitensis, B. suis, B. canis, B. neotomae, and B. ovis. Both bison (Bison bison) and elk (Cervus elaphus) in Yellowstone and Grand Teton National Parks (Wyoming, USA) are known to be infected with $B$. abortus biovar 1 (Davis, 1990). Free-ranging caribou (Rangifer tarandus) in Alaska are infected with B. suis biovar 4 (Davis, 1990). Moose (Alces alces) share the same habitat with these infected species and possibly come into contact with infected, aborted fetuses and other tissues; however, few reports exist of moose infected with either B. abortus or B. suis.

The few documented cases of free-ranging moose with $B$. abortus infections describe severely debilitated animals exhibiting symptoms including fibrinous myocarditis, pericarditis, and peritonitis ( $\mathrm{Da}-$ vis, 1990). Honour and Hickling (1993) reported a weak moose from the MacKenzie River (Northwest Territories, Canada) naturally infected with $B$. suis biovar 4, showing large fluctuant carpal masses with bilateral bursitis and osteomyelitis. A survey by Zarnke (1983) found one of 39 moose in Alaska had a weak serologic reaction for Brucella sp. specific antibodies. However, studies in British Columbia, Alberta, and Quebec (Canada) of a combined 356 moose herd failed to find any animals with significant levels of Brucella sp. specific antibodies (Hudson et al., 1980; Bourque and Higgins, 1984; Zarnke and Yuill, 1981). Experimental inoculation of moose with B. suis biovar 4 or B. abortus biovar 1 has been shown to produce a strong antibody response and severe disease in some animals (Dieterich et al., 1991; Forbes et al., 1996). Due to the severity of symptoms and limited number of documented moose with brucellosis, it has been postulated that dissemination throughout the herd may be self-limited (Zarnke, 1983; Forbes et al., 1996). However, six northern free-ranging moose cows in Alaska with strong serologic reactions for Brucella sp. specific antibodies have survived in the field for more than $1 \mathrm{yr}$ (O'Hara et al., 1998). Also, two of these moose raised calves that were still alive 1 yr following parturition. 
A key component used to differentiate the different Brucella spp. is the structure of the O-polysaccharide chain found on the lipopolysaccharide (LPS). The O-polysaccharide of B. abortus biovar 1, causative agent of brucellosis in bison, elk, and cattle in the continental United States, consist primarily of a linear homopolymer of $\alpha 1,2$ linked 4,6-dideoxy-4-formamido-D-manno-pyranosyl residues, commonly referred to as the $\mathrm{A}$ antigen or $\mathrm{A}^{+} \mathbf{M}^{-}$(Meikle et al., 1989). In contrast, B. melitensis biovar 1 , a serious cause of human and caprine brucellosis throughout the Middle East, contains O-polysaccharide made up of a predominately linear pentasaccharide repeating unit composed of four $\alpha 1,2$-linked and one $\alpha 1,3-$ linked sugars, commonly referred to as the $\mathbf{M}$ antigen or $\mathrm{A}^{-} \mathbf{M}^{+}$. The $\mathrm{A}$ and $\mathrm{M}$ antigens elicit antibodies of different specificity, allowing differentiation based on serology. Unlike B. abortus biovar 1 type strain 2308 (S2308) or B. melitensis biovar 1 type strain 16M (S16M), B. suis biovar 4 elicits the production of both $\mathrm{A}$ and $\mathrm{M}$ antigen specific antibodies $\left(\mathrm{A}^{+}\right.$ $\mathrm{M}^{+}$) from the host. This is because the $\mathrm{O}-$ polysaccharide of $B$. suis biovar 4 has a 1 : 7 ratio of $\alpha 1,3$-linked to $\alpha 1,2$-linked sugars as compared to the $1: 4$ ratio of $S 16 \mathrm{M}$. Therefore, animals infected with $B$. suis biovar 4 should elicit the production of both $\mathrm{A}$ and $\mathrm{M}$ antigen specific antibodies unlike S2308 $\left(\mathrm{A}^{+} \mathbf{M}^{-}\right)$or S16M $\left(\mathbf{A}^{-} \mathbf{M}^{+}\right)$ infected animals (Meikle et al., 1989).

Here we report the identification of both $\mathrm{A}$ and $\mathrm{M}$ antigen specific antibodies by western immunoblot in serum collected from free-ranging northern Alaskan moose with a higher prevalence of antibody to Brucella spp. than expected (O'Hara et al., 1998). Data from this study suggests that these moose from northern Alaska were exposed to B. suis biovar 4 .

Sera were obtained from moose from the Colville River and associated drainages (near Umiat, North Slope Borough, Alaska; $69^{\circ}-70^{\circ} \mathrm{N}, 153^{\circ}-151^{\circ} \mathrm{W}$; O'Hara et al., 1998). All samples were obtained by venous jugular puncture on anesthetized an- imals as described previously (O'Hara et al., 1998). A combined total of 54 moose serum samples were obtained in two studies from 1996 and 1997. Six animals from the 1996 study were positive on the standard card test (Alton et al., 1975) for agglutinating antibodies to B. abortus biovar 1. Four of the six 1996 card test positive animals remained positive for agglutinating antibodies to B. abortus biovar 1 in 1997. Also, an additional two animals from the 1997 study were found to possess agglutinating antibodies. All 54 samples, including the 12 card test positive samples (representing 8 animals) along with 12 negative and 15 positive controls, were submitted for analysis by western immunoblot. A blind study was done with the results being recorded qualitatively to identify negative and positive animals. The western immunoblot was used only as a research tool and no attempt was made to verify it as an official diagnostic test.

Sera were again analyzed by the card test (Alton et al., 1975) and western immunoblot (Schurig et al., 1991). These two tests were selected because the card test is an accepted field agglutination test, and the western immunoblot is a sensitive direct binding assay able to detect as little as $1 \mathrm{ng}$ of protein (Harlow and Lane, 1988). Western immunoblot analysis was performed using cell lysates from $B$. abortus S2308, B. melitensis S16M, and B. suis biovar 4. Cell lysates were obtained by sonication and dilution in Laemmli sample buffer (Schurig et al., 1991). Electrophoresis and transfer to nitrocellulose were performed according to Schurig et al. (1991). Briefly, electrophoresis was performed with a BioRad Mini-Protean II unit (Hercules, California, USA) utilizing the Laemmli discontinuous SDS-PAGE method with $15 \mu \mathrm{l}$ of cell lysate per $20 \mu \mathrm{l}$ well. Nitrocellulose transfer was performed for $1 \mathrm{hr}$ with $150 \mathrm{~V}$ in a Mini TransBlot Electrophoretic Transfer Cell (BioRad). Following transfer the blots were blocked with a $5 \%$ nonfat milk buffer for 30 min followed by washing with tris-buff- 
ered saline containing $0.5 \%$ Tween-20. Three adjoining membrane lanes containing the three cells lysates were then incubated for $1 \mathrm{hr}$ at $37 \mathrm{C}$ with a 1:40 dilution of the test serum. Subsequently, the blots were washed and incubated with rabbit anti-bovine IgG horseradish peroxidase conjugate (Sigma Chemical Company, Saint Louis, Missouri, USA) at a dilution of 1:800 for $30 \mathrm{~min}$ at room temperature. After washing, the substrate 4-chloro-1naphthol (Sigma) was added for color development.

To perform the absorption assay, whole killed cells of S2308, S16M, and B. suis biovar 4 were obtained by formalin fixing a fresh culture of each strain. Serum from each animal was diluted 1:9 in tris-buffered saline and divided into four $1 \mathrm{ml}$ aliquots. To three $1 \mathrm{ml}$ samples, $10 \mathrm{mg}$ of whole killed cells from either S2308, S16M, or B. suis biovar 4 were added. As a control, no cells were added to the fourth aliquot. The diluted serum was then incubated for $1 \mathrm{hr}$ at $37 \mathrm{C}$. Following incubation, the samples were centrifuged at $14,000 \mathrm{rpm}$, and the aqueous unbound serum removed from the cellular debris. Serum was then analyzed by western immunoblot, as described above, at concentrations of 1:40 and 1:400 per sample.

Serum absorbed with each strain of brucellae was compared to the unabsorbed control following a five min development. Typically, Brucella spp. O-polysaccharide from the LPS produces a nondiscrete, ladder-like profile from 29 to $68 \mathrm{kDa}$ when run on a SDS-PAGE gel (Allen et. al., 1998). The binding of anti-O-polysaccharide antibodies to this protein ladder during a western immunoblot produces a dark smear from 29 to $68 \mathrm{kDa}$ based on protein markers ran concurrently on the same gel (Allen et. al., 1998). Positive reactions were qualitatively recorded as either faint, medium, or dark. A faint reaction was characterized by a slight color halo along the ladder that was light enough to allow visualization of the many different protein bands present from 29 to $68 \mathrm{kDa}$. A me- dium reaction was dark enough to prevent the visualization of some protein bands, and a dark reaction caused the complete coverage of every protein band along the smear. As positive controls, sera from six cattle experimentally infected with $B$. abortus S2308, six goats infected with $B$. melitensis $\mathrm{S} 16 \mathrm{M}$, and three pigs infected with $B$. suis biovar 4 also were tested along with 12 known negative controls.

Western immunoblot analysis found the 12 card test positive sera samples (representing 8 individual animals) to have antibodies specific for both $\mathrm{A}$ and $\mathrm{M}$ antigen O-polysaccharide. Furthermore, an additional animal that was card test negative for agglutinating antibodies against $B$. abortus was found to have antibodies against both $\mathrm{A}$ and $\mathrm{M}$ antigens by western immunoblot. All 13 western immunoblot positive moose samples (representing 9 individuals) with antibodies for Brucella sp. were from the Colville River area as described by O’Hara et al. (1998).

The sera from the 13 western immunoblot positive samples, 12 negative controls, and three experimentally infected pigs were then analyzed by absorption with whole killed cells from S2308, S16M, and B. suis biovar 4 prior to western immunoblot analysis. Absorption of the sera with S2308 whole killed cells, containing a majority of A antigen O-polysaccharide, caused a decrease in only two of the 13 test samples. However, sera absorption with S16M containing predominately $\mathrm{M}$ antigen O-polysaccharide caused an appreciable decrease in western immunoblot reactivity to both $B$. suis biovar 4 and S16M cell lysates. Absorption with B. suis biovar 4 led to a decrease in reaction intensity to cell lysates from both predominately $\mathrm{A}^{+} 2308$ and $\mathrm{M}^{+}$S16M indicating the presence of antibodies against both antigens in the sera. The results of two representative serum samples are shown in Table 1. These results were unaffected whether the serum was diluted 1:40 or 1 : 400. Similar results were obtained from 
TABLE 1. Western immunoblot analysis of two Alaskan moose serum samples using cell lysates from $B$ abortus biovar 1 type strain 2308 (S2308), B. melitensis biovar 1 type strain 16M (S16M), and B. suis biovar 4 .

\begin{tabular}{|c|c|c|c|c|c|c|c|c|c|c|c|c|}
\hline \multirow{2}{*}{$\begin{array}{l}\text { Animal } \\
\text { number }\end{array}$} & \multicolumn{3}{|c|}{ No absorption } & \multicolumn{3}{|c|}{ Absorbed with S2308 } & \multicolumn{3}{|c|}{ Absorbed with S16M } & \multicolumn{3}{|c|}{$\begin{array}{l}\text { Absorbed with } \\
\text { B. suis biovar } 4\end{array}$} \\
\hline & $\mathrm{A}^{\mathrm{a}}$ & B & $\mathrm{C}$ & A & B & $\mathrm{C}$ & A & B & $\mathrm{C}$ & A & B & $\mathrm{C}$ \\
\hline $\mathrm{M} 20^{\mathrm{b}}$ & $3^{c}$ & 1 & 2 & 1 & 2 & 3 & 2 & 0 & 0 & 2 & 0 & 0 \\
\hline $\mathrm{M} 703^{\mathrm{b}}$ & 3 & 1 & 2 & 3 & 2 & 2 & 2 & 1 & 1 & 2 & 1 & 1 \\
\hline${ }^{+}$controld & 3 & 1 & 2 & 1 & 2 & 3 & 2 & 0 & 0 & 2 & 0 & 0 \\
\hline${ }^{-}$controle & 0 & 0 & 0 & 0 & 0 & 0 & 0 & 0 & 0 & 0 & 0 & 0 \\
\hline
\end{tabular}

a $\mathrm{A}=\mathrm{S} 2308$ cell lysate, $\mathrm{B}=\mathrm{S} 16 \mathrm{M}$ cell lysate, $\mathrm{C}=\mathrm{B}$. suis biovar 4 cell lysate

${ }^{\mathrm{b}}$ Moose card test positive for Brucella sp. specific antibodies.

$\mathrm{c}^{\mathrm{c}} 0=$ no reaction with cell lysate by western immunobot, $1=$ faint reaction, $2=$ medium reaction, $3=$ dark reaction $($ See text for explanation).

d Pig experimentally infected with B. suis biovar 4 .

e Moose card test negative for Brucella sp. specific antibodies.

the three pigs experimentally infected with B. suis biovar 4 (Table 1 ).

Meikle et al. (1989) showed that while B. abortus biovar 1 contains a predominance of the $\alpha 1,2$-linked $\mathrm{O}$-polysaccharide, A antigen, it also has a small number of $\alpha 1,3$-linked O-polysaccharide, $\mathrm{M}$ antigen, epitopes at a ratio of $18 \mathrm{~A}$ antigens to $2 \mathrm{M}$ antigens. Furthermore, B. melitensis biovar 1 contains a small number of $\mathrm{A}$ antigens at a ratio of one A antigen per $19 \mathrm{M}$ antigens. These strains have been designated typical $\mathrm{A}$ and $\mathrm{M}$ strains with each epitope composed of five sugar units. Animals infected with $B$. abortus biovar 1 will make antibodies primarily directed against A antigen, and $B$. melitensis biovar 1 infected animals make antibodies primarily against the $\mathbf{M}$ antigen. For B. suis biovar 4, which expresses both $\mathrm{A}$ and $\mathbf{M}$ antigens, epitopes were found to consist of seven continuous sugar units as compared to the typical five (Meikle et al., 1989). Hence, animals with B. suis biovar 4 infections produce an abundance of antibodies against both the $\mathbf{M}$ and $\mathrm{A}$ antigens. However, a dominance of $\mathbf{M}$ antigens in B. suis biovar 4 explains the fact that absorption of the reactive moose sera with whole killed cells of S16M, but not S2308, caused a decrease in reactivity to $B$. suis biovar 4 cell lysate by western immunoblot. The dominance of the $\mathbf{M}$ antigen also may have caused the moose to produce a higher proportion of
M antigen specific antibodies. This may explain why absorption of the test sera with S2308 whole killed cells caused a decrease in only two of the 13 samples tested. However, the data does indicate that the moose were producing antibodies to both the $\mathrm{A}$ and $\mathbf{M}$ epitopes, characteristic of $B$. suis biovar 4 infections.

Data from this study suggest that these northern Alaskan moose from the Colville River area were exposed to B. suis biovar 4, a pathogen known to occur at varying annual rates in Arctic Alaskan caribou herds and other species.

We wish to thank the many individuals involved in obtaining the sera and for providing us with samples. We specifically thank members of the Alaska Department of Fish and Game, including G. Carroll, L. Anne Ayres, and R. Zarnke. We thank J. Bevins and J. Blake for initial serologic testing and consultation. Technical assistance in the field was provided by C. Hanns, C. Willetto, and K. Burek.

\section{LITERATURE CITED}

Allen, C. A., L. G. Adams, And T. A. Ficht. 1998. Transposon-derived Brucella abortus rough mutants are attenuated and exhibit reduced intracellular survival. Infection and Immunity 66: 1008-1016.

Alton, G. G., L. M. Jones, And D. E. Pietz. 1975. Laboratory techniques in brucellosis. World Health Organization Press, Geneva, Switzerland, pp. 1-163. 
Bourque, M., And R. Higgins. 1984. Serologic studies on brucellosis, leptospirosis, and tularemia in moose (Alces alces) in Quebec. Journal of Wildlife Diseases 20: 95-99.

DAVIS, D. S. 1990. Brucellosis in wildlife. In Animal brucellosis, K. Nielsen and J. R. Duncan (eds.). CRC Press Inc., Boca Raton, Florida, pp. 321334.

Dieterich, R. A., J. K. Morton, and R. L. Zarnke. 1991. Experimental Brucella suis biovar 4 infection in a moose. Journal of Wildlife Diseases 27: $470-472$.

ENRIGHT, F. M. 1990. The pathogenesis and pathobiology of Brucella infection in domestic animals. In Animal brucellosis, K. Nielsen and J. R. Duncan (eds.). CRC Press Inc., Boca Raton, Florida, pp. 301-320.

Forbes, L. B., S. V. Tessaro, and W. Lees. 1996. Experimental studies on Brucella abortus in moose (Alces alces). Journal of Wildlife Diseases 32: 94-104.

HARLOW, E., AND D. LANE. 1988. Immunobloting. Antibodies, a laboratory manual. Cold Spring Harbor Laboratory 12: 421-470.

Honour, S., AND K. M. H. Hickling. 1993. Naturally occurring Brucella suis biovar 4 infection in a moose (Alces alces). Journal of Wildlife Diseases 29: 596-598.
Hudson, M., K. N. Child, D. F. Hatler, K. K. FUJINO, AND K. A. Hodson. 1980. Brucellosis in moose (Alces alces). A serological survey in an open range cattle area of north central British Columbia recently infected with bovine brucellosis. Canadian Veterinary Journal 21: 47-49.

Meikle, P. J., M. B. Perry, J. W. CherwonogroDZKY, AND D. R. BUNDLE. 1989. Fine Structure of $\mathrm{A}$ and $\mathrm{M}$ antigens from Brucella biovars. Infection and Immunity 57: 2820-2828.

O'Hara, T. M., J. DaU, G. Carroll, J. Bevins, and R. L. ZarnKe. 1998. Evidence of exposure to Brucella suis biovar 4 in northern Alaska moose. Alces 34: 31-40.

Schurig, G. G., R. M. Roop, T. Bagchi, S. Boyle, D. Buhrman, and N. SRIRAnganathan. 1991. Biological properties of RB51; A stable rough strain of Brucella abortus. Veterinary Microbiology 28: 171-188.

ZarnKe, R. L., AND T. M. YUILL. 1981. Serologic survey for selected microbial agents in mammals from Alberta, 1976. Journal of Wildlife Diseases 17: 453-461.

- 1983. Serologic survey for selected microbial pathogens in Alaskan wildlife. Journal of Wildlife Diseases 19: 324-329.

Received for publication 3 September 1998. 